\title{
Unusual incidence of chronic pneumonia associated with cholesterol deposits in stranded and bycaught franciscanas Pontoporia blainvillei
}

\author{
Valeria Ruoppolo ${ }^{1,2, *}$, Ralph Eric Thijl Vanstreels ${ }^{3}$, Juliana Marigo ${ }^{2,4}$, \\ José Luiz Catão-Dias ${ }^{3}$ \\ ${ }^{1}$ Emergency Relief Team, International Fund for Animal Welfare, 290 Summer Street, Yarmouth Port, Massachusetts 02675, USA \\ ${ }^{2}$ Projeto BioPesca, Praia Grande, SP, Brazil \\ ${ }^{3}$ Departamento de Patologia, Faculdade de Medicina Veterinária e Zootecnia, \\ Universidade de São Paulo, São Paulo, SP, Brazil \\ ${ }^{4}$ Laboratório de Mamíferos Aquáticos e Bioindicadores (MAQUA), Faculdade de Oceanografia, \\ Universidade do Estado do Rio de Janeiro, Rio de Janeiro, RJ, Brazil
}

\begin{abstract}
Franciscanas Pontoporia blainvillei are small dolphins endemic to Brazil, Uruguay and Argentina. During routine pathologic examinations, chronic pneumonia associated with cholesterol deposits was found in $16.7 \%$ of stranded and incidentally bycaught franciscanas ( $\mathrm{n}=60)$, and was more frequent in dolphins from the Brazilian state of São Paulo (Franciscana Management Area II) and frequently accompanied by splenic lymphoid hyperplasia. It is unclear why these otherwise uncommon lesions were relatively frequent in the studied dolphins, and further research is advised.
\end{abstract}

KEY WORDS: Marine $\cdot$ Pathology $\cdot$ Pontoporia blainvillei $\cdot$ Cholesterol pneumonia $\cdot$ Brazil

\section{INTRODUCTION}

Franciscanas Pontoporia blainvillei are small dolphins endemic to the shallow coastal and estuarine waters of the Atlantic coast of South America, from southeastern Brazil to Uruguay and northern Argentina (Secchi et al. 2002). This species is considered as endangered by Brazilian authorities and vulnerable by the IUCN (MMA 2003, Reeves et al. 2008); its main threat is related to incidental mortality in gillnet fisheries (Crespo et al. 1997, Bertozzi \& Zerbini 2002, Reeves et al. 2008). Recent studies have suggested that franciscana stocks may be divided into 4 proposed Franciscana Management Areas (FMAs) with the following ranges: FMA I coastal waters of Espírito Santo and Rio de Janeiro states, Brazili FMA II - São Paulo, Paraná and Santa Catarina states, Brazili FMA III - coastal waters of Rio Grande do Sul State, southern Brazil and Uruguay; and FMA IV coastal waters of Argentina, including the provinces of Buenos Aires, Rio Negro and Chubut (Secchi et al. $2002,2003)$. Besides drowning and trauma from entan- glement in fishing nets, parasitic and other infectious lung diseases are known to be major mortality causes of odontocetes (Kirkwood et al. 1997, Jauniaux et al. 2002, Marigo et al. 2002).

Lung cholesterol deposits associated with chronic pneumonias are generally infrequent lesions with characteristic morphologic features (Sadé et al. 1980, Sadé \& Teitz 1983, Jones et al. 1996, Caswell \& Williams 2007). As described in humans, cholesterol clefts are often found as sequelae to necrosis in any tissue, deriving from the aggregation of cholesterol and other lipids from cell membranes (Fisher \& Beyer 1959, Jones et al. 1996, Caswell \& Williams 2007). Haemorrhage has been traditionally implicated in the pathogenesis of these lesions (Jones et al. 1996, Fischer et al. 2000), and it is also believed that local muco-inflammatory secretions, such as lung surfactants, also have an important role as a source of cholesterol deposition (Sadé \& Teitz 1983, Nolan et al. 1999). Hypoventilation has also been strongly proposed to be an important factor in the pathogenesis of cholesterol granulomas (Sadé et al. 
1980, Sadé \& Teitz 1983, Terao et al. 2001, Leon et al. 2002), and hypercholesterolemia could also be involved (Sullivan et al. 1961). Alveolar proteinosis secondary to irritant gases, drug-induced excessive production of surfactant, accidental or gastric refluxderived oil inhalation, altered immunity or locally produced toxic agents, partial obstruction of airways, pulmonary hypertension or embolism from artherosclerothic plaques are all known to cause lung cholesterol granulomatous pneumonia in humans (Sullivan et al. 1961, Hruban 1984, Gondouin et al. 1996, Sabatine et al. 1997, Nolan et al. 1999, Caswell \& Williams 2007, Moldveen-Geronimus \& Merriam 2009). In odontocetes, these lesions were observed on the cerebellum of a common dolphin Delphinus delphis reacting to the presence of trematode eggs (Howard et al. 1983a). In this study, we report the finding of such cholesterolassociated lesions in the lungs of stranded and incidentally bycaught franciscanas, as identified during routine pathologic examinations.

\section{MATERIALS AND METHODS}

From 1996 to 2002 a total of 107 franciscanas were found stranded on beaches or were incidentally captured by fishing nets in Argentina and Brazil (Fig. 1),
60 of which (36 male, 23 female, 1 undetermined gender) were found in sufficiently well-preserved condition to allow necropsy and subsequent histological examination, all within the period of 1998-2001. Within 24 to $48 \mathrm{~h}$ of death, the carcasses were necropsied and sampled by the technical staff of local institutions or by the authors, following procedures recommended by Rommel \& Lowenstine (2001). Age group was determined based on body length (flattened chord along the body; juveniles $<125 \mathrm{~cm}$, adults $>125 \mathrm{~cm}$ ) and/or according to the institution's report. Each institution reported the context in which each carcass was received, and these were classified into 3 categories: bycatch $(\mathrm{n}=54)$, stranding $(\mathrm{n}=4)$ and rehabilitation (live strandings taken into rehabilitation centres but perished shortly thereafter; $\mathrm{n}=2$ ).

Carcasses were examined and major organs and tissues were fixed in $10 \%$ buffered formalin and embedded in paraffin. Sections of $5 \mu \mathrm{m}$ were obtained, stained with haematoxylin \& eosin and examined under light microscopy; in selected cases, additional histochemical stains were also used to evidence particular elements (Luna 1992). Swabs from tissues with suspected bacterial infections (as indicated by gross findings) were transferred to Stuart's transport medium (or hemoculture medium, for cardiac blood) and immediately refrigerated, then submitted to routine aerobic bacterial (blood

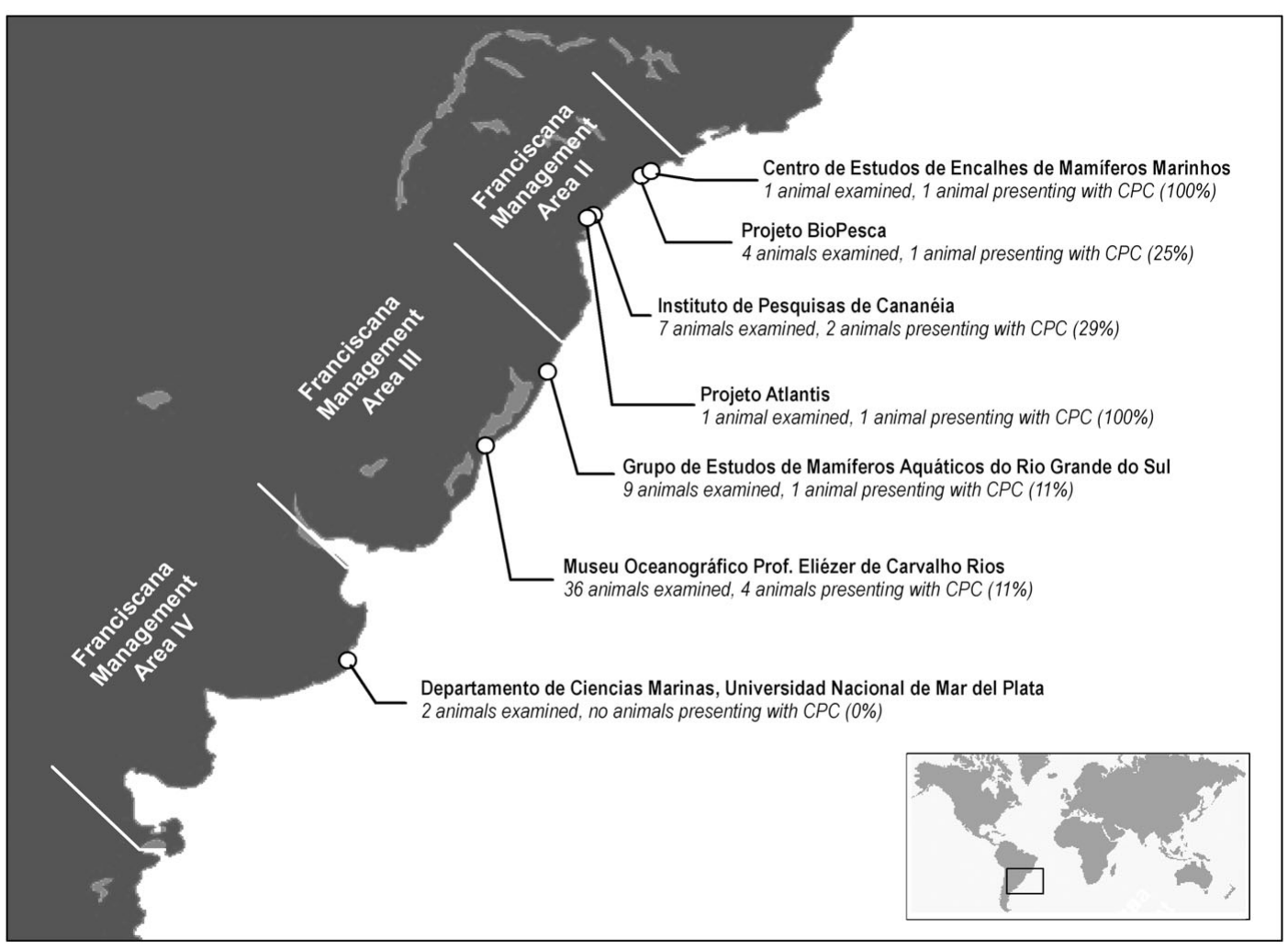

Fig. 1. Geographic distribution of Franciscana Management Areas, study institutions and specimens of franciscana Pontoporia blainvillei presenting with chronic pneumonia associated with cholesterol deposits (CPC) 
agar and MacConkey plates, $37^{\circ} \mathrm{C}$ for $7 \mathrm{~d}$ ) and fungal cultures; cultures were characterized through biochemical (Biochemical Identification API System, Biomerieux) or morphological methods (Barnett \& Hunter 1998). Body weight or its natural logarithm did not present a normal distribution (Anderson-Darling test), and was compared among groups with the Mann-Whitney test. Comparisons on the incidence of lesions among groups were performed by arranging data in contingency tables and testing with the chi-square test (or with Fisher's exact test when the chi-square's pre-requisites were not met). Significance level was 0.05 for all tests.

\section{RESULTS}

Ten of the 60 histopathologically examined franciscanas $(16.7 \%)$ had chronic pneumonia associated with cholesterol deposits (CPC) (Fig. 1); lesions associated with cholesterol were not found in other tissues of any studied animals.

At gross examination, the lungs presented multifocal coalescent areas with diameters of 1 to $10 \mathrm{~mm}$; these areas were pale yellow and homogeneous in appearance, with firm consistency. These lesions were predominantly distributed in multifocal patches along the peripheral edges of both lungs, affecting relatively small areas of the lungs $(<10 \%$ of lung parenchyma, V. Ruppolo pers. obs.). Lesions were typically visible on the pleural surface, but could also be found deeper within the lung parenchyma. In some cases fibrinous

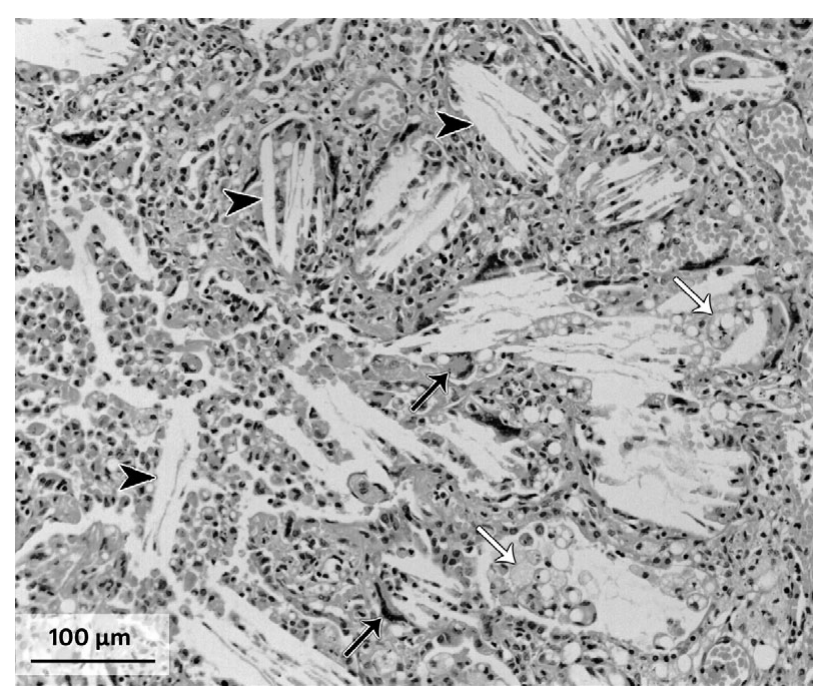

Fig. 2. Pontoporia blainvillei. Histopathologic appearance of lungs from P. blainvillei (CEEMAM 111; see Table 1). Chronic pneumonia associated with cholesterol deposits; note the presence of abundant cholesterol clefts (black arrowheads), foamy macrophages (white arrows) and giant cells (black arrows). H\&E stain, 200× pleuritis was present at the pleura surrounding the lesions. Histopathological examination revealed these lesions presented as multifocal areas with numerous cholesterol clefts surrounded by multinucleated giant cells (both Langhans and foreign body types were present with variable proportions in each case) and abundant foamy macrophages (Fig. 2). Granulocytic infiltrates, fibrin, fibroplasia, epithelioid cells, alveolar fetalization and epithelial shedding were present to different degrees among cases; some cases presented characteristic granulomas, while others presented as predominantly chronic mononuclear cell infiltration, without a granulomatous pattern, along with active granulocytic involvement. In at least one case the areas of cholesterol granulomatous pneumonia presented multifocal granulocytic infiltration associated with rare bacterial rods, suggesting these lesions may provide favourable environment for secondary bacterial infections.

The incidence of these lesions was not significantly different among genders (male, female), age groups (neonate, juvenile, adult) or contexts of death (bycatch, stranding, rehabilitation) (Fisher's exact test, all $\mathrm{p}>$ 0.05). On the other hand, animals from the Brazilian state of São Paulo (FMA II) presented a higher incidence $(4 / 10)$ than those from Rio Grande do Sul state (FMA III; 5/45) (Fisher's exact test, $\mathrm{p}=0.047$; animals from Argentina were not included in the comparisons due to small sample size). Body weight of adults (Mann-Whitney test, $U=27, \mathrm{p}=0.211$ ) or juveniles $(W=96.5, \mathrm{p}=0.423)$ did not significantly differ based on presentation of CPC.

No lung parasites were found in the studied franciscanas. Intestinal parasites were found and details are reported elsewhere (Marigo et al. 2002). Table 1 summarizes the pathological findings on the individuals with CPC. Pneumonia unassociated with cholesterol deposits occurred concurrently in $20 \%$ of the animals with CPC (2/10), and was present in $18 \%$ of the remaining animals (9/50) (Fisher's exact test, p = $0.668)$. Fifty percent of the animals with these lesions $(5 / 10)$ presented reactive splenic lymphoid hyperplasia, whereas this finding was present in only $16 \%$ of the remaining animals (8/50) (Fisher's exact test, $\mathrm{p}=$ 0.031); reactive lymphoid hyperplasia was determined qualitatively by 2 independent observers, and was characterized as the expansion of lymphocytic populations with confluence of periarteriolar lymphoid sheaths (or lymphoid follicles, in the case of lymph nodes) and the presence of pronounced germinal centers. On the other hand, about $40 \%$ of the animals both with and without CPC (4/10 and 21/50, respectively) had liver congestion (chi-square test, $\chi^{2}=0.014$, $\mathrm{df}=1$, $\mathrm{p}=0.907$ ). Moderate to severe lung congestion and oedema were common findings in virtually all by- 
Table 1. Pontoporia blainvillei. Pathological findings of 10 franciscanas presenting with chronic pneumonia associated with cholesterol deposits in the Southwest Atlantic, 1998-2001

IPEC 055 - Male, juvenile, 11.7 kg. Bycatch, 31/1/1998. Cananéia, SP, Brazil.

Lungs: congestion, severe; oedema, severe; pneumonia, chronic, granulomatous by cholesterol crystals, multifocal, coalescent, moderate. Intestinal parasites: 13 Hadwenius pontoporiae.

MO-CA 176 - Male, adult, $26.7 \mathrm{~kg}$. Bycatch, 25/6/1998. Rio Grande, RS, Brazil.

Lungs: congestion, severe; oedema, severe; pneumonia, chronic, granulomatous by cholesterol crystals, focal, moderate. Liver: congestion, moderate; hepatitis, granulocytic, diffuse, associated with granulocytic leukocytosis, moderate. Lymph nodes: reactive lymphoid hyperplasia, severe.

GEMARS 0531 - Female, adult, 25.5 kg. Bycatch, 11/7/1998. Porto Alegre, RS, Brazil.

Lungs: atelectasis, lobar, severe; congestion, severe; oedema, severe; haemorrhage, diffuse, severe; pneumonia, chronic, granulomatous by cholesterol crystals, multifocal, coalescent, moderate.

MO-CA 194 - Female, juvenile, 29.5 kg. Bycatch, 18/8/1998. Rio Grande, RS, Brazil.

Lungs: pneumonia, chronic, granulomatous by cholesterol crystals, lobar, moderate; congestion, moderate; oedema, subpleural, associated with aforementioned areas of granulomatous pneumonia; haemorrhage, diffuse, moderate. Liver: congestion, moderate.

IPEC 119 - Male, juvenile, 15.5 kg. Bycatch, 15/12/1998. Cananéia, SP, Brazil.

Lungs: congestion, severe; oedema, severe; haemorrhage, multifocal, severe; pneumonia, chronic, granulomatous by cholesterol crystals, multifocal, coalescent, moderate. Intestinal parasites: 84 Hadwenius pontoporiae.

ATLANTIS 132 - Female, adult, 19.2 kg. Stranding, 16/6/1999. Cananéia, SP, Brazil.

Lungs: pleuropneumonia, multifocal, moderate; congestion, moderate; oedema, moderate; pneumonia, chronic, granulomatous by cholesterol crystals, multifocal, coalescent, moderate. Spleen: reactive lymphoid hyperplasia. Thoracic lymph nodes: reactive lymphoid hyperplasia. Skin: recent traumatic lesions on the head, compatible with gillnet interaction.

MO-CA 205 - Male, juvenile, 21.4 kg. Bycatch, 6/11/1999. Rio Grande, RS, Brazil.

Lungs: congestion, moderate; oedema, moderate; pneumonia, chronic, granulomatous by cholesterol crystals, multifocal, coalescent, moderate. Stomach: submucosa, pyogranuloma, focal, causal agent undetermined after Gram and PAS staining Spleen: reactive lymphoid hyperplasia.

MO-CA 208 - Male, adult, $27.8 \mathrm{~kg}$. Bycatch, 29/11/1999. Rio Grande, RS, Brazil.

Lungs: congestion, severe; oedema, severe; haemorrhage, moderate-severe; pneumonia, chronic, granulomatous by cholesterol crystals, multifocal, coalescent, moderate. Liver: congestion, moderate. Spleen: reactive lymphoid hyperplasia; lymphocytolysis, individual, multifocal.

CEEMAM 111 - Male, juvenile, 12 kg. Bycatch, 30/8/2000. Santos, SP, Brazil.

Lungs: pneumonia, associated with cholesterol crystals, multifocal, coalescent, moderate, with mononuclear infiltrate; pneumonia, interstitial, acute, multifocal, moderate, with bacterial rods, associated to aforementioned areas of granulomatous pneumonia; congestion, moderate; oedema, moderate; haemorrhage, diffuse, moderate. Spleen: reactive lymphoid hyperplasia.

BIOPESCA 31 - Male, juvenile, 8.2 kg. Bycatch, 14/5/2001. Praia Grande, SP, Brazil.

Lungs: pleuropneumonia, chronic, diffuse, moderate-severe; pneumonia, chronic, granulomatous by cholesterol crystals, multifocal, coalescent, moderate. Liver: congestion, moderate; necrosis, focal, locally extensive, with exuberant ductal hyperplasia, fibrin deposits, minor fibroplasia; haemosiderosis, discrete. Spleen: reactive lymphoid hyperplasia. Lymph nodes: lymphadenitis, multiple sites, diffuse, moderate. Penis: balanitis, moderate; hematoma. Eye: opaque left crystalline. Intestinal parasites: 9 Hadwenius pontoporiae. Bacterial cultures: cardiac blood (negative), thoracic cavity swab (negative), thoracic cavity fluid (Micrococcus sp.), lungs (Staphylococcus sp. in 3 separate cultures). Fungal cultures: heart blood (negative), thoracic cavity swab (negative).

caught animals, regardless of the presence (8/9) or absence (41/45) of CPC (Fisher's exact test, $\mathrm{p}>0.990)$. The only stranded animal with $\mathrm{CPC}$ had recent lesions on the head compatible with gillnet interactions, and is likely to have stranded as a consequence.

\section{DISCUSSION}

The unusual and relatively high incidence of chronic pneumonia associated with cholesterol deposits without an identified cause in the franciscanas studied is surprising. The microscopic presentation of these lesions was very similar to those described in cholesterol-associated lesions in other mammals (Sullivan et al. 1961, Sadé et al. 1980, Sadé \& Teitz 1983, Jones et al. 1996, Fischer et al. 2000, Caswell \& Williams 2007). Lung congestion and oedema were common findings in all bycaught franciscanas, and these are the typical findings in cetaceans asphyxiated in gillnets; drowning in these species is always presented as a dry obstructive asphyxiation once there is no agonic inhalation of water (Lipscomb 1996, Gulland et al. 2001). This makes it difficult to determine which level of congestion or oedema was present in association with CPC before drowning. 
To our knowledge, the only report of cholesterol clefts and granulomas in cetaceans was made by Howard et al. (1983a), who reported those found in the cerebellum of a common dolphin Delphinus delphis, reacting to the presence of trematode eggs. There was no evidence of lung parasitism in any of the examined franciscanas. Cholesterol deposits could be signs of lesions from past parasite infection; however, this is unlikely in these cases considering there are no parasites known to occur in the lungs of franciscanas (Marigo et al. 2002). On the coast of the Brazilian state of Paraná, up to $88 \%$ of the sympatric marine tucuxi dolphin Sotalia guianensis have pulmonary nematode infections (Halocercus brasiliensis), and yet no cholesterol-associated lung lesions were found in those specimens (Marigo et al. 2010), suggesting pulmonary parasites may not play a significant role in inducing cholesterol-associated lung lesions.

The relatively small portions of lung parenchyma affected by these lesions in the studied animals suggest that those were not major pathological conditions, but most likely secondary necropsy findings. The peripheral distribution of these lesions on the lung suggests that this might have been due to local hypoventilation from anatomical position, possibly associated with secondary alveolar proteinosis from this chronic anatomical hypoxic stress, but this has yet to be confirmed.

Other probable causes may be considered. Chronic exposure to volatile oil contaminants or other toxic gases and vapours could explain the cholesterol pneumonia, since this can cause irritation of the lung parenchyma, with necrosis, haemorrhage and augmented surfactant secretion. There is intense naval activity and a few large industrial cities along the coasts of both FMA II and FMA III, which could be possible sources of chronic oil and toxic contamination for the studied animals (Alonso 2008). Toxic gases and vapours, depending on their water solubility and intensity of lung irritation induced, would be expected to be most absorbed in highly ventilated areas of parenchyma or evenly throughout the lung parenchyma (Haschek \& Rousseaux 1998); however, the peripheral distribution observed in the lesions argues against this hypothesis as it suggests that areas of parenchyma poorly ventilated due to their anatomical position were most affected.

Another hypothesis is that pulmonary infectious processes, inducing areas of lung consolidation and atelectasis, could have caused the hypoxic microenvironment in which cholesterol pneumonias tend to develop (Howard et al. 1983b). Two of the 10 CPC cases studied (both from São Paulo state, Brazil) had concomitant pleuropneumonic lesions (see Table 1), and in one of these cases Staphylococcus sp. was iso- lated from lung swabs; however, a similar frequency of pneumonias unassociated with cholesterol deposits was observed in the remaining animals. The finding that splenic hyperplasia was more frequent in franciscanas with CPCs may also be considered to support the hypothesis of infectious involvement in these lesions, suggesting that a chronic inflammatory response may have concurred with the development of the cholesterol lesions. Alonso (2008) and Souza (2010) studied franciscanas at the São Paulo coast and identified a possible influence of organochloride contamination on splenic hypoplasia; toxicants may be an additional factor modulating the immune response of these animals, and might also affect the development of cholesterol pneumonias. There is evidence that marine mammals are subject to chronic organochlorine contamination along the coast of Brazil in both management areas, and it is possible but yet unclear if differences in contamination along these areas could be related to the studied lung lesions (Yogui et al. 2003, Fillmann et al. 2007, Alonso 2008). Hypercholesterolemia may also act as a predisposing factor for the development of cholesterol deposits (Sullivan et al. 1961); it has been shown in other dolphin species that elevated plasma lipids may be associated with gender (females > males), age (juveniles > adults), seasonality, migration and pregnancy (Aubin et al. 2001, Terasawa \& Kitamura 2005, Fair et al. 2006). Chronic lung haemorrhage secondary to pulmonary hypertension, coagulation disorders or exposure to amphiphilic drugs were considered unlikely to explain the lesions at the relatively high incidence observed.

It is unclear if the studied franciscanas presented such incidence of CPCs as a direct indication of a high prevalence of these lesions in the general population, or if those lesions are directly or indirectly associated with the causes that led animals to become bycaught or stranded. It is possible that species-specific anatomical and physiological variations make these lesions a relatively common finding in franciscanas without significant health implications, but this cannot be assumed without additional evidence. The finding that these lesions were present at higher frequency in FMA II than in FMA III suggests that species-specific variations may not provide a complete explanation and that other environmental factors are likely to be involved. Although the studied specimens date back to 1998-2001, franciscanas with compatible gross lesions are still found frequently (C. Bertozzi pers. comm.). Further studies are advised to detect if these lesions are similarly frequent elsewhere and identify consistent patterns and underlying causes, so their relevance in terms of fitness and survival of franciscanas may be clarified. 
Acknowledgements. We are grateful to the following institutions and their staff for collecting and submitting their samples: Centro de Estudos de Encalhes de Mamíferos Marinhos (CEEMAM), Projeto BioPesca, Instituto de Pesquisas de Cananéia (IPeC), Projeto Atlantis, Grupo de Estudos de Mamíferos Aquáticos do Rio Grande do Sul (GEMARS), Museu Oceanográfico (MO-FURG; Prof. E. de Carvalho Rios) and Laboratório de Ciências Marinas de la Universidad Mar del Plata. This research was supported by the São Paulo Research Foundation (FAPESP 99/12335-8, 00/14669-0). J.L.C.D. is the recipient of a scholarship by Conselho Nacional de Desenvolvimento Científico e Tecnológico (CNPq 301517-2006-1).

\section{LITERATURE CITED}

Alonso MB (2008) Organoclorados em toninhas, Pontoporia blainvillei (Mammalia: Cetacea) da região costeira do Estado de São Paulo, Brasil. MS dissertation, Oceanography Institute, University of São Paulo, São Paulo

Aubin DJS, Deguise S, Richard PR, Smith TG, Geraci JR (2001) Hematology and plasma chemistry as indicators of health and ecological status in Beluga whales, Delphinapterus leucas. Arctic 54:317-331

Barnett JA, Hunter BB (1998) Illustrated genera of imperfect fungi. Burgess Publishing, Minneapolis, MN

Bertozzi CP, Zerbini AN (2002) Incidental mortality of franciscana (Pontoporia blainvillei) in the artisanal fishery of Praia Grande, São Paulo state, Brazil. Lat Am J Aquat Mamm 1(Spec Issue):153-160

Caswell JL, Williams KJ (2007) Respiratory system. In: Maxie MG (ed) Jubb, Kennedy \& Palmer's pathology of domestic animals. W. B. Saunders, Philadelphia, PA

Crespo EA, Pedraza SN, Dans SL, Alonso MK, Reyes LM, García NA, Coscarella M (1997) Direct and indirect effects of the high seas fisheries on the marine mammal populations in the Northern and Central Patagonian coast. J Northwest Atl Fish Sci 22:189-207

Fair PA, Hulsey TC, Varela RA, Goldstein JD, Adams J, Zolman ES, Bossart GD (2006) Hematology, serum chemistry, and cytology findings from apparently healthy Atlantic bottlenose dolphins (Tursiops truncatus) inhabiting the estuarine waters of Charleston, South Carolina. Aquat Mamm 32:182-195

Fillmann G, Hermanns L, Fileman TW, Readman JW (2007) Accumulation patterns of organochlorines in juveniles of Arctocephalus australis found stranded along the coast of southern Brazil. Environ Pollut 146:262-267

Fischer EG, Marek JM, Morris A, Nashelsky MB (2000) Cholesterol granulomas of the lungs associated with microangiopathic hemolytic anemia and thrombocytopenia in pulmonary hypertension. Arch Pathol Lab Med 124: 1813-1815

Fisher ER, Beyer FD (1959) Postinflammatory tumor (xanthoma) of lung. Dis Chest 36:43-48

- Gondouin A, Manzoni P, Ranfaing E, Brun J and others (1996) Exogenous lipid pneumonia: a retrospective multicentre study of 44 cases in France. Eur Respir J 9:1463-1469

Gulland FMD, Lowenstine LJ, Spraker TR (2001) Noninfectious diseases. In: Direaulf LA, Gulland FMD (eds) Handbook of marine mammal medicine. CRC Press, Boca Raton, FL

Haschek WM, Rousseaux CG (1998) Fundamentals of toxicologic pathology. Academic Press, London

Howard EB, Britt JO, Matsumoto GK (1983a) Parasitic diseases. In: Howard EB (ed) Pathobiology of marine mammal diseases. CRC Press, Boca Raton, FL
Howard EB, Britt JO, Matsumoto GK, Itahara R, Nagano CN (1983b) Bacterial diseases. In: Howard EB (ed) Pathobiology of marine mammal diseases. CRC Press, Boca Raton, FL

- Hruban Z (1984) Pulmonary and generalized lysosomal storage induced by amphiphilic drugs. Environ Health Perspect 55:53-76

Jauniaux T, Petitjean D, Brenez C, Borrens M and others (2002) Post-mortem findings and causes of death of harbour porpoises (Phocoena phocoena) stranded from 1990 to 2000 along the coastlines of Belgium and northern France. J Comp Pathol 126:243-253

Jones TC, Hunt RD, King NW (1996) Cells: death of cells and tissues. In: Jones TC, Hunt RD, King NW (eds) Veterinary pathology. Williams \& Wilkins, Baltimore, MD

> Kirkwood JK, Bennett PM, Jepson PD, Kuiken T, Simpson VR, Baker JR (1997) Entanglement in fishing gear and other causes of death in cetaceans stranded on the coasts of England and Wales. Vet Rec 141:94-98

> Leon ME, Chavez C, Fyfe B, Nagorsky MJ, Garcia FU (2002) Cholesterol granuloma of the maxillary sinus. Arch Pathol Lab Med 126:217-219

Lipscomb TP (1996) Pathologic findings in dolphins known to have died from underwater entrapment. In: Kuiken T (ed) Diagnosis of bycatch in cetaceans. In: Kuiken T (ed) Proceedings of the Second European Cetacean Society workshop on cetacean pathology. European Cetacean Society, Montpellier, 2 March 1994, p 1-3

Luna LG (1992) Histopathologic methods and color atlas of special stains and tissue artifacts. American Histolabs, Gaithersburg, MD

Marigo J, Rosas FCW, Andrade ALV, Oliveira MR, Dias RA, Catão-Dias JL (2002) Parasites of franciscana (Pontoporia blainvillei) from São Paulo and Paraná states, Brazil. Lat Am J Aquat Mamm; (LAJAM) 1:115-122

Marigo J, Ruoppolo V, Rosas FCW, Valente ALS, Oliveira MR, Dias RA, Catão-Dias JL (2010) Helminths of Sotalia guianensis (Cetacea: Delphinidae) from the south and southeastern coasts of Brazil. J Wildl Dis 46: 599-602

MMA (Ministério do Meio Ambiente) (2003) Instrução Normativa 3 de 22 de maio de 2003. Ministério do Meio Ambiente, Brasília

Moldveen-Geronimus M, Merriam JC (2009) Cholesterol embolization: from pathological curiosity to clinical entity. Circulation 35:946-953

Nolan RL, McAdams HP, Sporn TA, Roggli VL, Tapson VF, Goodman PC (1999) Pulmonary cholesterol granulomas in patients with pulmonary artery hypertension: chest radiographic and CT findings. AJR Am J Roentgenol 162: 1317-1319

Reeves RR, Dalebout ML, Jefferson TA, Karczmarski L and others (2008) Pontoporia blainvillei. In: IUCN 2010. IUCN Red List of Threatened Species. Version 2010.2, available at www.iucnredlist.org

Rommel SA, Lowenstine LJ (2001) Gross and microscopic anatomy. In: Dierauf LA, Gulland FMD (eds) CRC handbook of marine mammal medicine. CRC Press, Boca Raton, FL

Sabatine MS, Oelberg DA, Mark EJ, Kanarek D (1997) Pulmonary cholesterol crystal embolization. Chest 112: 1687-1692

Sadé J, Teitz A (1983) Cholesterol and cholesteatoma. Acta Otolaryngol 95:547-553

Sadé J, Halevy A, Klajman A, Mualem T (1980) Cholesterol granuloma. Acta Otolaryngol 89:233-239

Secchi ER, Danilewicz D, Ott PH, Ramos R, Lazaro M, Marigo J, 
Wang JY (2002) Report of the working group on stock identity. Lat Am J Aquat Mamm 1:47-54

Secchi ER, Danilewicz D, Ott PH (2003) Applying the phylogeographic concept to identify franciscana dolphin stocks: implications to meet management objectives. J Cetacean Res Manag 5:61-68

Souza PC (2010) Imunoexpressões pulmonar e esplênica das citocinas IL-12, TGF-b e TNF-a e das proteínas Lisozima e S-100 em Pontoporia blainvillei (Gervais e d'Orbigny, 1844) (Mammalia, Cetacea). Master's dissertation, University of São Paulo, São Paulo

Editorial responsibility: Michael Moore,

Woods Hole, Massachusetts, USA
Sullivan JJ, Ferraro LR, Mangiardi JL, Johnson EK (1961) Cholesterol pneumonitis. Chest 39:71-76

Terao T, Onoue H, Hashimoto T, Ishibashi T, Kogure T, Abe T (2001) Cholesterol granuloma in the petrous apex: case report and review. Acta Neurochir 143:947-952

Terasawa F, Kitamura M (2005) Hyperlipemia of captive bottlenose dolphins during pregnancy. J Vet Med Sci 67: 341-344

Yogui GT, Santos MCO, Montone RC (2003) Chlorinated pesticides and polychlorinated biphenyls in marine tucuxi dolphins (Sotalia fluviatilis) from the Cananéia estuary, southeastern Brazil. Sci Total Environ 312:67-78

Submitted: March 30, 2010; Accepted: June 23, 2010

Proofs received from author(s): September 10, 2010 